\title{
Social Media as the Virtual Public Sphere Ahead of the 2019 General Election in Indonesia
}

\author{
Muhammad Edy Susilo and Prof. Pawito \\ Department of Communication, Universitas Sebelas Maret, Sutami Street 36A, Surakarta, Indonesia \\ muh_edy_susilo@yahoo.co.id,bung_pawito@yahoo.com
}

Keywords: Social media, democracy, hoax

\begin{abstract}
Social media is one of many online platforms on the internet. This research chose Facebook among existing social media sites to analyze its context as a virtual public sphere ahead of the 2019 Indonesian General Election. Democracy requires freedom of expressions from every party. Social media is one of the platforms that can carry out that function. The research is using the Political Economy of New Media as the theoretical approach. In this qualitative research study, the data is collected through in-depth interview. The results showed that on one hand, the social media has the power to increase the citizens' democratic participation. However, on the other hand, they are the source of hoax and digital data leakage. Seemingly, the Indonesian Government has not yet anticipated this problem through the internet use regulations in the upcoming General Election. The law enforcement also has not yet shown any justice regarding the problems within social media use. The use of social media is overshadowed by the digital capitalization overshadowed that might affect the implementation of democracy.
\end{abstract}

\section{INTRODUCTION}

The number of internet users in Indonesia has kept growing. In 1998, there were only around 500,000 internet users in Indonesia. Meanwhile, based on a survey held by Indonesian Internet Service Provider Association (Asosiasi Penyelenggara Jasa Internet Indonesia - APJII), the Indonesian internet users in 2017 has reached 142 million with a percentage of $54.69 \%$ from its total population. The internet users have grown $7.9 \%$ from the previous year and have increased more than $600 \%$ in the last 10 years. This number positioned Indonesia as the $6^{\text {th }}$ biggest internet users after China, America, India, Brazil, and Japan (Databoks, 2018).

A data has shown that social media is the most commonly used platform on the internet in Indonesia. Boyd and Ellison define social network as a "web-based service" that allows a user to 1) build a public or quasi-public profile in the system, 2) get connected with other users in which they can communicate with each other, 3) interact with other account users in the system (Danah Boyd, 2008).

Currently, Indonesia has been listed as having a big number of social media users. Based on a research by We are Social, a media company from England incorporation with Hootsuite, on average, Indonesian spent 3 hours 23 minutes per day to access the social media. There were around 130 million active social media users from the total population of 265.5 million with a percentage of around 49\% (Pertiwi, 2018). In a row, social media sites that were mostly accessed by Indonesian are YouTube (43\%), Facebook (41\%), Whatsapp (40\%), Instagram (38\%), Line (33\%), BBM (28\%), and Twitter (27\%) (Databoks, 2018).

The correlation between the internet as the new media and democracy is an interesting study. Some researchers have stated the correlation between those two concepts before. The media is a place for the citizens or political candidates to have reciprocal communication both to inform and influence. Beside the acknowledgment of the media importance in political communication, another thing that needs to be considered is the setting where the communication is carried out. In the political contexts, the intended setting is the type of the political regime (Mughan, Gunther, 2000).

Some examples clearly showing the successful struggle against a tyrant government with the fall of some political regimes in the Middle East and North 
Africa, like Tunisia, Egypt, Yemen, and Libya. There is no hesitation about the role of social media in those events, especially in Egypt. The demonstrators recorded all the occurrences using their mobile phones and uploaded them to Facebook or YouTube. Many also did a frequent live streaming. They spread the information from their country via Facebook, coordinate through twitter, and blog intensively to express and discuss their opinions (Castells, 2012).

In this article, the internet and social media are referred to as a virtual public sphere. It was taken from the concept of public sphere popularized by Jurgen Habermas, even though he was not the first theorist that concepts such idea. The public sphere is formed as a space in which political discourse may happen between a nation and its society. It helps in liberating the people from the tyrannical authority to let them debate as one form of political action.

In reality, undoubtfully, there is no inclusive public space like what has been stated before. Habermas notifies that occupying the public space using money and authority may result in culture homogeneity, lack of public discourse, and centralization of power in taking a decision. These processes lead to the society in which only one perspective is allowed and there is no more room for discussion.

The virtual public space on the internet is wider and more direct than anything else imagined by any sociologist and political theorist. Christian Fuchs refers to it as virtual communities that so far it is much easier to access and more participative than of a physical society (Clio, 2018).

This research is using the Political Economy of New Media approach. One of the ideas in the theory is that the media becomes the first industry that is able to produce and distribute a commodity (Murdock, Golding, 1995). Olive Boys Barret has made an observation and found that political economy has a critical meaning. It is not only focusing on the authority and control of the media but also other factors that unite the media industry with politic, economy, and elite society.

The Internet has developed a "digital capitalism" which may create a global network of capitalism in the social and cultural sector. The latter is generalized by a capitalist economy that newly exists. Capitalism can develop production and capital accumulation through a) rationalization of production and work productivity through information and communication technology, b) media concentration, communication, and culture industry proprietors, and c) production and selling of immaterial commodities including science, information, and entertainment (Flew, 2014).

The increasing use of social media in Indonesia ahead of the 2019 General Election is an interesting topic to study. The Presidential Candidates competing in the 2014 General Election had used social media to increase the support from the people. A research carried by Susilo shows that the team of Jokowi (Joko Widodo, one of the presidential candidates) understood the characteristics of social media networks in building perception, opinion, and impression towards personal branding (Susilo, 2015). The research question is how the role of social media, especially Facebook, becomes the virtual public sphere ahead of the 2019 Indonesian General Election.

\section{METHODOLOGY}

This research was carried out using a qualitative approach. The data was collected through in-depth interview and media text analysis. The informants of this research were the social media activists, social media analysts, and the government (Ministry of Communication and Informatics and Public Relations of the Indonesian National Police). The criteria for selecting the social media activists were having a least 100,000 followers and is active in posting political issues in social media. The contents could be in form of texts, pictures, or videos. The data analysis was developed in making sense of the data, interpreting or transforming the data in form of narration directed to findings under the nuance of scientific propositions (thesis), and finally reaching the conclusion (Pawito, 2007).

\section{RESULT AND DISCUSSION}

\subsection{Mass media and social media}

In the election before the social media era, the conventional mass media, like printed media, television, radio, and outdoor media was commonly used for promotions. These conventional media were managed in a very large and complex organization. Thus, the government could easily regulate and control their existence.

There is something new in the 2019 General Election. Formerly, the campaign regulations were issued by the General Election Commission (Komisi 
Pemilihan Umum - KPU). For General Election 2019 however, the regulations were set out in the Act No. 7 of 2017. There are some interesting parts to be observed within the regulations. Firstly, there is a separated regulation related to the internet and social media. The Internet is included in the same category as printed and electronic mass media, while social media is set to be in another point. Secondly, the act states that the campaign is to be conducted in the period of 21 (twenty one) days until the Grace Period or three days before the election. This regulation only ruled the conventional mass media as it is difficult to be applied for social media and internet.

There are many anonymous users in the social media and internet because they simply have an access. They can freely campaign in the social media. At least, there are three actors involved in a political communication activity in the social media, they are the buzzer, influencer, and supporter (Nasution, 2018). This makes the political campaign in social media becomes difficult to monitor when we are using the mass conventional media approach.

\subsection{Hoax}

Generally, the definition of a hoax is as a fake news. It is an act with an intention to trick people into believing something is real when it is not (Info, 2018). Referring to the similar references, the etymology of the term hoax is believed to be derived from hocus or something has spoken quickly and there is also hokum, which is a blend of hocus-pocus and "bunkum" or "bunk". Novi Kurnia, one of the informants in this research, stated:

"A hoax is a fake news or inaccurate information-not because of unpunctuality, but deliberateness." (Kurnia, 2018).

The deliberateness becomes an important aspect to discuss in the production of a hoax. Novi, a researcher, and activist of Japelidi (Jaringan Peneliti Literasi Digital - Digital Literacy Researcher Network), categorizes a hoax actor as both the maker and spreader. The maker deliberately makes hoax containing misleading information as intended, while the spreader may have various reasons in spreading the hoax, e.g. low level of understanding the hoax, nescience, or just being chimed in.

The political hoax had spread widely in the 2014 General Election and had split Indonesian society into two big groups the supporter of Jokowi (Joko Widodo) dan Prabowo (Susilo, 2015). This polarization can be felt during Jokowi's presidential era in 2014-2019. It will be predicted to continue until the 2019 General Election. Besides the hoax about Jokowi and Prabowo, the target can be religious figures, House of Representatives, Indonesian National Armed Force, Indonesian National Police, and many others.

The spread of hoax in Indonesia tends to escalate ahead of the 2019 General Election. The consequences of the hoax can affect social anxiety and national disintegration. Each group in society can be suspected, prejudiced. This may lead to counterproductive in the life of a nation.

There are two main cause of the hoax spreading which are social media users' low level of literacy and problems in the law enforcement. In the aspect of quantity, the number of social media users in Indonesia has been growing quickly, but their quality is quite low. Freedom in expressing opinion that becomes the characteristic of democracy tends to be misused in social media.

In another side, the government has not shown any effort through law enforcements to prevent the spread of hoax and hate speech on social media. So far, the Government has taken a serious legal action to some community groups that spread hoax and hate speech, for example, Saracen and Muslim Cyber Army (MCA). Both of them were accused of being syndicates that spread hoax and hate speech that harms the National Integration. However, the judicial process could never prove the accusation in which Saracen web administrators received a funding of over a hundred million rupiahs after posted a series of hate speech (Saubani, 2018). The case of spreading hoax and hate speech done MCA is still in the trial process until today.

The effort of the government in handling the hoax is considered unfair because it only processes those that oppose the government. The spreading hoax and hate speech done by the accounts supporting the government are never being legally processed. The police were quick in processing cases related to the critics towards the government but rather slow in responding or do not at all process the pro-government hoax cases (Damhuri, 2018).

Jonru, one of the convicts on the case of spreading the hoax and hate speech, has stated the similar thing in 2018. He had 1,481,578 followers on his fan page as the police detained him (Jonru, https://web.facebook.com/jonru.page/, 2018).

"The government is unfair in eradicating hoax. Under Jokowi's government, the Muslims were marginalized. Consequently, the level of trust in the government decreases. That is why many people become vigilant." (Jonru, 2018). 
Jokowi has held several private meetings with some social media activists that support him in the presidential palace (Ihsanudin, 2018). This strengthens the public assumption that the Indonesian government applies a double standard in dealing with the case of spreading the hoax and hate speech.

\subsection{Data leakage}

Communication in the convergent media has a chance of experiencing a data leakage. All the data in the social media are digitally recorded and can be used for any interest. The scandals of Wikileaks (Leigh, 2018) and Edward Joseph Snowden are two big cases related to data leakage that can affect the exacerbation of the relationship between certain countries (Auliani, 2018).

Big social media site such as Facebook has also experienced data leakage. There were as many as $1,096,666$ Indonesian or around $1.26 \%$ of the total number of people around the world that are affected by the leakage (Safitri, 2018). The leakage became a National issue and emerged a concern on the weakening of information security in Indonesia during the digital era. The data that was leaked could be exploited for political and economic interests.

The data on the internet can be mined and managed. It is called "Big Data" as it has an enormous number. The data, which has been collected, can be beneficial on one hand, but also dangerous on the other hand. Moreover, Cathy O'Neil called it the Weapon of Destruction (WMD). The proprietors of the media that hold the data can use it for any interest. Besides, the unequal ownership of the data within social groups or nations in the world would create inequality and become a threat to democracy (O'Neil, 2017).

The proprietors of the media have an authority to apply regulations in which all users must agree. The social media utilizes bubble filter that makes the users may feeling comfortable in a blanket of ideas and views that can never be discussed with the opposing opinions. As stated by Zygmunt Bauman:

"Most people do not use social media to unite and widen their horizon, instead to force themselves to stay in their own safe zone in which the only voice they can listen is their own and the only thing they can see is the reflection of themselves." (Leetaru, 2018).
O'Neil's statement shows the dark side of digital technology that becomes the basis of social media. Democracy can only develop if all party stand on the same side. However, the internet can raise the socalled "digital capitalism". This process accelerates historically unique transition that is opening global capitalism network. The network then will directly rationalize the range of social, culture, and economy capitalism that never happened before (Schiller, 2000).

On one side, the social media is providing its user an access to freedom of speech as required in a democratic process. However, on the other side, the use of social media has a dangerous side that may give devastating impacts to the democracy.

At the micro level, there is an evidence that Indonesian people do not have a sufficient digital literacy. The freedom of speech is mostly not used for a mean of healthy public discussions. Most of them get stuck easily in the spreads of negative contents like the hoax. The low level of digital literacy is likely to be harmful because it has the potential to cause disintegration.

Meanwhile, at the macro level, the government has problems with the regulation on social media and its implementation. Yet, one of the important pillars of the democracy is a fair consequence for all the perpetrators. However, the government looks duplicitous, in which it gains profit from the social media that gives them support, while it is very strict to the opposing party on the social media. This kind of behavior can be a boomerang for the government in the future.

In the global level, social media users have involved in the digital capitalism that can hold network power to gather any data from the users and keep it in the big data. The proprietors of social media, like Facebook, have the authority that had never been possessed by the proprietors of the previous media. The big data can be used for both political and economic interest.

Democracy is about providing freedom of speech for everyone and in which all decisions are made by a consensus. The dictatorship is the place in which a single entity makes the rule for the society without any input from those that the rule is for. The social media platform currently rules with absolute power in launching new regulations, banishing the members, and acting as the main arbiter of information on what can be discussed or consumed. How can a platform that rules by absolute power give help in a democracy based on the consensus and collaboration? 


\section{CONCLUSION}

Social media can be a space for the citizen in expressing their opinions. On the other hand, it also has some concerning aspects. In the implementation of democracy, social media can appear as a danger instead of a democratic enforcement. Proprietors in the digital media have a big authority since they are the ones who set the use of social media. All the data shared by the users can be put into the database owned by the proprietors while they can use the data for their own interests in the future.

The use of social media in this technologically advanced condition creates another problem as the citizen has a low level of digital literacy. The Government's weakness in forming social media regulations can also be a problem. They appreciate the support that they from one side of the netizen (Internet Citizen). Meanwhile, they can be harsh and unfair towards their opposing party. Had this continue to happen, the quality of democracy in the society will decline. This can also result in creating society's disintegration.

Through this research, we suggest that the government should form social media regulations and implement them fairly. The government and the citizen need to continuously educate themselves to be more digitally literate. Considering the fact that social media operates globally, the government is also hoped to initiate an International agreement regarding the use of social media that can improve the quality of democracy.

\section{REFERENCES}

Andrew F. Wood, M. J. S., 2005. Online Communiation Linking Technology, Identity and Culture. New Jersey: Lawrence Erlbaum Associates.

Anon., 2018. [Online] Available at: http://wordinfo.info/unit/3408/s:hoax

Anthony Mughan, R. G., 2000. The Media in Democratic and Nondemocratic Regimes: A Multilevel Perspective. In: Democracy and the Media A Comparative perspective. Cambridge: Cambridge University Press, pp. 1-27.

Auliani, P. A., 2018. [Online] Available at: https://internasional.kompas.com/read/2014/07/11/013 31281/Jerman.Usir.Perwakilan.CIA.di.Berlin

Barr, T., 2000. newmedia.com. Sidney: Allen \& Unwin.

Beers, D., 2006. The Public Sphere and Online, Independent Journalism. Canadian Journal of Education, pp. 109-130.
BPS, 2017.

Available

at:

https://www.bps.go.id/dynamictable/2017/12/21/1276/ indeks-demokrasi-indonesia-idi-menurut-indikator2009-2016.html

Clio,2018. http://clioscurrent.com/blog/2013/9/19/thevirtual-public-sphere. [Online].

Damhuri,E.,2018. Available at: http://nasional.republika.co.id/berita/nasional/newsanalysis/18/03/03/p4z3mz440-apakah-pemerintahtebang-pilih-dalam-kasus-mca

Danah Boyd, Nicole B. Ellison, 2008. Social Networking Sites: Definition, History and Scholarship. Journal of Computer-Mediated Communication, pp. 210-230.

Databoks, 2018. [Online] Available at: https://databoks.katadata.co.id/datapublish/2018/02/01 /media-sosial-apa-yang-paling-sering-digunakanmasyarakat-indonesia

Databoks, 2018. [Online] Available at: https://databoks.katadata.co.id/datapublish/2018/02/2 O/berapa-jumlah-pengguna-internet-di-indonesia.

Dijk, J. V., 2006. The Network Society: Social Aspect of New Media. London: Sage.

Ferawati, 2017. Available at: repository.unpas.ac.id/28315/4/BAB\%20II.pdf

Flew, T., 2000. New Media: an Introduction. Melbourne: Oxford University Press.

Flew, T., 2014. New Media. Melbourne: Oxford University Press.

Ihsanudin, 2018. [Online] Available at: https://nasional.kompas.com/read/2017/08/24/152351 41/jokowi-gelar-pertemuan-tertutup-dengan-pegiatmedia-sosial

Info, W., 2018. Available at: http://wordinfo.info/unit/3408/s:hoax

Jonru, 2018. [Online] Available at: https://web.facebook.com/jonru.page/

Jonru, 2018. Media Sosial, Hoax dan Ujaran Kebencian [Interview] (8 May 2018).

Kurnia, N., 2018. Literasi Digital Bagi Masyarakat Sipil [Interview] (4 Maret 2018).

Leetaru, K., 2018 https://www.forbes.com/sites/kalevleetaru/2018/01/2 5/without-transparency-democracy-dies-in-thedarkness-of-social-media/\#672bab617221. [Online].

Leigh, D., 2018. [Online] Available at: https://www.theguardian.com/world/2010/nov/28/us -embassy-cable-leak-diplomacy-crisis

Lutfie, N., 2018. Media Sosial dan Hoax [Interview] (1 Maret 2018).

Manuel Castells, 2012. Networks of Outrage and Hope. Cambidge: Polity.

Nasrullah, R., 2016. Teori dan Riset Media Siber (Cybermedia). Jakarta: Prenadamedia Group.

Nasution, E., 2018. [Online] Available at: http://enda.goblogmedia.com/?p=4477 
O'Neil, C., 2017. Weapons of Math Destruction, How Big Data Increases Inequality and Threatens Democracy. Great Britain: Penguin Books.

Pawito, 2007. Penelitian Komunikasi Kualitatif. Yogyakarta: LKiS.

Safitri, A., 2018. [Online] Available at: https://www.cnnindonesia.com/teknologi/20180417 122443-185-291365/data-bocor-penggunafacebook-di-indonesia-bertambah
Saubani, A., 2018. [Online] Available at http://nasional.republika.co.id/berita/nasional/hukum /18/04/06/p6rhlj409-hakim-saracen-tak-terbuktisebarkan-ujaran-kebencian

Schiller, D., 2000. Digital Capitalism: Networking The Global Market System. Cambridge: MIT Press.

Susilo, M. E., 2015. Pemilihan Umum Indonesia 2014 dan Penggunaan Social Media, Yogyakarta: UPN "Veteran" Yogyakarta. 